\title{
Upiorne oblicze systemu
}

\author{
Božidar Jezernik, Naga wyspa. Gulag Tity, przeł. J. Pomorska, J. Slawińska, \\ Wydawnictwo Czarne, Wołowiec 2013, 357 s.
}

Božidara Jezernika przedstawiać nie trzeba, jego książki, takie jak Dzika Europa. Bałkany w oczach zachodnich podróżników (2007) i Kawa (2011) są dobrze znane i cenione na polskim rynku czytelniczym. W ubiegłym roku, nakładem Wydawnictwa Czarne, ukazała się kolejna pozycja tego autora i wzbudziła duże zainteresowanie zarówno ze względu na głośne nazwisko, jak i samą tematykę, nieobecną dotąd w świadomości wielu odbiorców. Polskie wydanie zostało opatrzone uderzającym, wywołującym silne skojarzenia, tytułem Naga wyspa. Gułag Tity, co wydaje się zabiegiem zarówno poznawczym, popularyzatorskim, jak i marketingowym. Rzecz jasna, przyniósł on pożądany skutek. Czytelnik z tej części Europy, obarczony doświadczeniem totalitaryzmów, wychowany na literaturze obozowej/łagrowej, przechowujący pamięć o ponurych czasach i ofiarach zbrodniczych systemów, zareaguje na samo słowo gułag. Można mniemać, że podobną intencję miał sam autor, jednak oryginalny tytuł: Non cogito ergo sum. Arheologija neke šale, który w polskim tłumaczeniu mógłby brzmieć: Non cogito ergo sum. Archeologia pewnego żartu (najwyraźniej ze względu na zagranicznego adresata), nie ma odpowiedniego ciężaru gatunkowego. Tymczasem dla wtajemniczonych i znawców tematu to interesująca i rozpoznawalna, równie jaskrawa co przekład, etykieta, która zachowując znaczeniowy ładunek, zostaje w dość lekki sposób wprowadzona w grę skojarzeń i reminiscencji. Już od samego początku widać, jak bardzo posępna, choć niepozbawiona humorystyczno-absurdalnego zabarwienia, będzie problematyka książki. Autor przywołuje żart krążący w titowskiej Jugosławii, o tym, że po II wojnie światowej pewien człowiek wykrzyknął: „Precz ze Stalinem!”, 
za co na długo trafił do więzienia; kiedy po odbyciu kary, na dowód udanej resocjalizacji, zawołał: „Niech żyje Stalin!”, został - zapewne ku swemu zdumieniu - powtórnie skazany na pozbawienie wolności. Dowcip dotyczy przełomowego roku 1948, kiedy doszło do konfliktu Tity ze Stalinem i, uchwałą Kominformu, do potępienia przywódców Komunistycznej Partii Jugosławii. Nastąpiła fala aresztowań rzeczywistych i domniemanych zwolenników sowieckiej rezolucji, zwanych kominformowcami. „Czas terroru zastąpił czas wojny" podsumowuje Jezernik (s. 13). Ruszyła machina represji, powstał program reedukacji - nawracania na socjalistyczną wiarę, budowania więzień i obozów tzw. pracy społecznie użytecznej, które siały powszechny postrach, a według władz stanowiły elementarną zasadę pedagogiki (jakże charakterystyczną dla systemów totalitarnych), służącą konstruowaniu nowego lepszego człowieka, którego motto powinno brzmieć: „Nie myślę, więc jestem”. W takim klimacie, mimo wcześniejszej krytyki sowieckich łagrów, powstała kolonia karna - Naga Wyspa (Goli otok), tytułowa w polskiej edycji, a dodatkowo określona w niej mianem gułagu Tity. Za przyzwoleniem autora, w bliski oryginalnej wersji, a jednak odmienny sposób, nazwa ta nie tylko uruchamia mechanizm natychmiastowego i odpowiedniego łączenia faktów, ale również może i ma powodować zdziwienie, a nawet niedowierzanie czytelnika, nieadekwatne do serii wydawniczej Historia, w której tekst się ukazał. Osłupienie i nieufność są tym większe, że tekst przeczy utrwalonemu, także w Polsce, obrazowi wolnej od wschodniego reżimu, prozachodniej, względnie liberalnej i samorządnej Jugosławii. Adam Michnik pisze o tym w przedmowie (Morfologia Nagiej Wyspy) do polskiej publikacji, podkreślając, że przy dominującym w całym bloku postsowieckim zafałszowanym wizerunku tego największego na Bałkanach państwa, książka Jezernika szokuje opowieścią „o okrucieństwach stalinizmu antystalinowskiego”, jednocześnie stanowiąc „trafny komentarz do najwybitniejszych dokonań «literatury łagrów»: Sołżenicyna i Szałamowa, Borowskiego i Herlinga-Grudzińskiego" (s. 9).

Naga Wyspa była jednym z wielu upiornych wcieleń ówczesnego systemu. Przez długi czas oficjalnie nieistniejąca - celowo owiana tajemnicą, aby zdawała się jeszcze bardziej groźna, rozmyślnie niezaznaczana na mapie geograficznej, na ideologiczną zaś wpisana jako miejsce unieszkodliwiania realnych i potencjalnych zdrajców, wrogów partii i narodu; ośrodek dla zawróconych ze złej drogi i światopoglądowo uzdrawianych, 
początkowo tylko kominformowców, potem także ustaszy, czetników, đilasowców i zwykłych przestępców. Autor poświęca wiele uwagi genezie wyspy, odwołuje się do kształtujących europejską wspólnotę i kulturę mitycznych konstrukcji, schematów imaginacyjnych, tradycji antycznej, średniowiecznej i ludowej, wskazując tym samym na powtarzalność historii, wiecznie aktualne postawy, motywowane niezmiennym zbiorem/kanonem wyobrażeń; akcentuje zdolność ludzkości do okrucieństwa i zabójczego dla idei humanitaryzmu szaleństwa zbrodni. Antropologiczny wywód przeplata wieloma wątkami faktograficznymi, barwnymi, a nawet symbolicznymi. Pisze o rosyjskich jeńcach, przetrzymywanych tu przez Austriaków w czasie I wojny światowej i komentuje: „właśnie na tej wyspie zostawili swe kości akurat Rosjanie" (s. 47) - w miejscu, w którym potem zbudowano socjalistyczny, do złudzenia przypominający nazistowski, a wzorowany na sowieckim, obóz pracy i upodlenia proradziecko myślących, a także w ogóle lub z trwogi niemyślących, skazanych na niebyt ludzi, których dewizą - co sugeruje autor - mogłoby być: cogito ... czy non cogito... to i tak ergo non sum! W narracji o potwornościach wyspy, stanowiącej pars pro toto jedynie słusznego systemu, często pojawiają się bezpośrednie nawiązania do nazistowskich struktur zagłady. Można mówić o pewnym wariancie, połączeniu okrutnych strategii faszystowskich i socjalistycznych, z tym że te ostatnie, także zrodzone z braku szacunku dla życia ludzkiego, nie celowały w jego unicestwienie czy w najlepszym razie redukcję, ukierunkowane były raczej na morderczą (re)e(duk)a(cję), jawiąc się w tym względzie równie potwornymi jak te pierwsze (wzorcowe!).

Autor chłodnym, niemalże sprawozdawczym, tonem odmalowuje realia na wysysającej człowieczeństwo wyspie - lądzie wydrążonych ludzi („Wyspa wycisnęła już z ciebie wszystko, jesteś pusty”, s. 127). Prowadzi opowieść od momentu przyjęcia więźniów (zabierania ubrań i rzeczy osobistych, golenia głów itd.), jednoznacznie kojarzącego się z hitlerowskimi transportami i pędzenia nowo przybyłych wzdłuż szpaleru agresywnych „rezydentów” („Bicie określa świadomość”, s. 147), będącego swoistym obrzędem przejścia, przypominającym popularną w innych zniewolonych przez socjalizm krajach formę represji tzw. ścieżkę zdrowia, a wcześniej żywy w carskiej Rosji zwyczaj znany jako ,praszczęta” (s. 77). Opowiada o panującym w obozie głodzie („Głód w oczach, w kościach, w duszy”, s. 203), wymyślnych torturach, upokorzeniach (,nie zabijemy cię od razu, 
bo nie potrzebujemy tu bohaterów. My cię zgnoimy!”, s. 125), wreszcie też o wymyślnych karach - jak podkreśla - niezmiennych od starożytności, po czasy średniowiecznej inkwizycji, aż do straszliwego periodu nazistowskiego i stalinowskiego. Jezernik mówi o ich niezliczonych, wyrafinowanych wariantach („A choć nic nie krępowało wyobraźni, wybór kar faktycznie ograniczał się do czynów, które uchodziły za upokarzające, hańbiące", s. 149), takich jak: degradacja przez bojkot - utrata statusu więźnia równoznaczna $\mathrm{z}$ pozbawieniem elementarnych praw ludzkich, maltretowanie cielesne, w tym także seksualne, nade wszystko zaś znęcanie się psychiczne (,zniszczenie w każdym więźniu własnego ja”, s. 184), a także bezsensowne, wycieńczające roboty, takie jak przenoszenie kamieni z jednej sterty na drugą, kopanie dołów i ich natychmiastowe zasypywanie itd. Praca „społecznie użyteczna”, w rzeczywistości niemająca nic wspólnego z pożytkiem, była obliczona na „zabicie w więźniu ducha walki” (s. 258), upodlenie go do granic wytrzymałości, tylko po to, aby zrewidował swoje poglądy, a co najważniejsze: by udowodnił tę przemianę i trwał w poczuciu najgłębszej wdzięczności za ocalenie („Tito i partia otworzyli im oczy, by mogli pojąc całą głębię swojego upadku i zdrady. Dlatego winni są im dozgonną wdzięczność", s. 269). Jezernik wskazuje, że najgorsze w tym programie reedukacyjnym było to, że i w teorii, i praktyce funkcjonował on wyłącznie za sprawą samych osadzonych „pragnących naprawić swoje błędy” (a raczej do tego zmuszonych). Więźniowie wzajemnie na siebie donosili i jedni drugich upokarzali, dręczyli, katowali („Same sobie wykłuwałyśmy oczy - czego nie robią nawet kruki”, s. 140), aby przypodobać się władzy, przetrwać i uniknąć jeszcze większej przemocy i prześladowania. Kierownictwo obozu świadomie podsycało tę bratobójczą, rodzącą się i pogłębiającą nienawiść. Wykorzystywało między innymi uprzedzenia i stereotypy, tworząc na przykład z Bośniaków - powszechnie nielubianych, uważanych za podstępnych, okrutnych, zawziętych - ,oddziały uderzeniowe” wyspecjalizowane w biciu i torturowaniu współwięźniów, regulujące w ten sposób życie na wyspie. Autor eksponuje i dość szeroko opisuje obozową hierarchię, która w niewielkim stopniu odbiegała od porządku panującego w nazistowskich czy sowieckich miejscach zagłady - drobne różnice wynikały tylko ze specyfiki miejsca i czasu oraz samego systemu titowskiego. Charakteryzując tę pionową strukturę społeczną, Jezernik zwraca uwagę przede wszystkim na aspekt reedukacyjny, w którym należy definiować utrzymujący się ład na 
Nagiej Wyspie, gdzie w okrutny sposób zarządzali nie funkcjonariusze, lecz tzw. grupa uleczonych/nawróconych - renegatów. To ona zajmowała wśród skazańców najwyższą pozycję i decydowała o losie pozostałych: „bandy”, „dwuobrotowych”, „trójobrotowych”, „ludzi z ogonami” i innych, stanowiąc dla władzy narzędzie bezwzględnego rozrachunku z wrogami i zdrajcami, jednocześnie pozwalając jej zachować „czyste ręce”. Ten oddolny, sprawnie działający mechanizm, nazywano samorządem, który faktycznie był rodzajem eksperymentu, praktycznej weryfikacji Kardeljowskiej teorii socjalizmu samorządowego („,To jest samorząd: każdy każdego szpieguje, każdy każdemu coś podrzuca, wszyscy są stale podejrzani, ideologiczny trans. Jestem zdania, że Naga Wyspa była początkiem tej nowej epoki socjalizmu samorządowego", s. 146). Autor porusza wiele szczegółowych wątków, opierając swą opowieść w dużej mierze na relacjach świadków (byłych więźniów i strażników), opiniach historyków, publicystów czy też badaczy systemów politycznych, ideologicznych. W opisie gułagowej rzeczywistości zachowuje naukowy dystans, nie potęgując dodatkowo narracji subiektywnymi ocenami czy emocjonalnymi komentarzami, raczej dąży do odsłonięcia rzeczywistego, dotąd nieznanego szerszemu gronu odbiorców, upiornego oblicza ówczesnego systemu. Wskazuje i uwydatnia zarówno charakterystyczne dlań elementy oraz zasady funkcjonowania, jak i uniwersalne zasady ludzkiej egzystencji, postawy i zachowania człowieka zniewolonego, upodlonego, a jednocześnie niezmiennie gotowego do strasznych i niewyobrażalnych czynów.

Ogromną wartością książki jest samo podjęcie i prezentacja problemu, wciąż słabo obecnego w świadomości wielu, zwłaszcza podobnie doświadczonych, narodów, a także wpisanie go w szeroki kontekst historyczny, polityczny, kulturowy, dzięki czemu zagadnienie zyskuje walor ponadregionalny, ponadnarodowy, ponadczasowy. Jej wielką zaletą jest także samo stanowisko autora, który miejscami w nieco lapidarny, lecz słusznie wyważony sposób, a nawet, jak we wstępie podkreśla Adam Michnik, ,z chłodną precyzją chirurga" (s. 10), zrywa z oblicza okrutnego systemu woal - w potocznym przekonaniu - lżejszego czy wręcz liberalnego wariantu socjalizmu. 